\title{
Effect of Different PGR and Urea on Fruit Drop and Yield of Assam Lemon [Citrus limon (L.) Burm.]
}

\author{
Bidyarani Devi Senjam, S.R. Singh* and Hau Ngaih Lian
}

Department of Fruit Science, College of Horticulture and Forestry, Central Agricultural University, Pasighat-791102, Arunachal Pradesh, India

*Corresponding author

\section{Keywords \\ NAA, 2,4-D, Urea, \\ Fruit drop, Yield, \\ Assam lemon \\ Article Info \\ Accepted: \\ 20 June 2018 \\ Available Online: \\ 10 July 2018}

\section{A B S T R A C T}

The synthetic PGR like 2,4-D and NAA along with $1 \%$ urea were investigated on 7 years old trees of lemon cv. Assam Lemon planted with a spacing of 3x3m at the Fruit Research Farm, Department of Fruit Science, College of Horticulture and Forestry, Pasighat, Arunachal Pradesh. The results of the pooled data of winter and summer seasons revealed that the imposition of different treatments had a significant effect on reducing fruit drop and improving the yield of fruits. Among the different treatments, T 6 (NAA@ 20 ppm + 2,4-D@20 ppm + 1\% urea) was found to be most effective with maximum number of fruits/plant at harvesting stage (67.6), yield/plant $(8.29 \mathrm{~kg})$ and minimum fruit drop (13.91

$\%$ ) as compared to control (33.15\% fruit drop and yield $4.14 \mathrm{~kg} / \mathrm{plant}$ ). However, nonsignificant effect was found in plant height and canopy spread. Hence, the combination of recommended dose of fertilizers 100:100:100g NPK/plant/year along with $20 \mathrm{~kg}$ FYM and synthetic PGR NAA @ 20 ppm +2,4-D @ 20 ppm + 1\% urea foliar spray twice (after fruit setting and fully developed stage) were found to be efficient for increasing yield and productivity in Assam Lemon which can be recommended for reducing fruit drop of this main cultivar lemon for the North East region in the future.

\section{Introduction}

Assam Lemon [Citrus limon (L.) Burm.] is the important lemon cultivar of the North Eastern region of India. It belongs to the family Rutaceae and is originated in Assam. The cultivar is also known as Pat Nimboo in Western India, Seville Lemon in Andhra Pradesh and Nepali Oblong in some parts of the country (Chattopadhyay, 2007). It possesses a wide variety of culinary, industrial, dietery and medicinal uses associated with its high vitamin $\mathrm{C}$ content. In India, fresh lemon is primarily used in the preparation of soft drinks for imparting cooling effect in summer. It is also used for preparing pickles, squashes, jams, jellies and marmalades. Lemon essential oil is used for flavouring soft drinks, baked foods, confectioneries, etc. and also as a key ingredient in cosmetic industries. Leaves are used in tea and for preparing meat and seafood. Singh et al., (2014) mentioned the use of its fresh leaves and peel in the 
preparation of a natural herbal shampoo by boiling with rice water. Besides, insecticidal properties of lemon peel extract have also been reported ( $\mathrm{Su}$ and Horvat, 1982). The cultivation of this fruit is gaining popularity because of its large crop holding capacity, big size fruits and abundant juice content (Randhawa and Srivastava, 1986). Fruits are available throughout the year since it blooms continuously, though the spring bloom is the heaviest (Devi et al., 2011). Unfortunately, fruit drop has become a limiting factor for obtaining increased fruit production in citrus. It occurs at various stages of fruit development due to malnutrition (Ashraf et al., 2012), fungal attack (Lima et al., 2011) and hormonal imbalance (Khan et al., 2014; Agustí et al., 2006). Fruit drop is influenced by an abscission mechanism, which is held under check by a chain of physiological processes (Randhawa and Srivastava, 1986). Assam Lemon is facing fruit drop mainly after fruit setting and pre-mature fruit drop. However, there is no report for the control of pre mature fruit drop by the use of synthetic PGR for this important lemon variety of North East India. Keeping in view the above consideration, the present study was planned with the objectives to study the effect of different growth regulators and urea in controlling pre- harvest fruit drop and to increase yield and productivity of this fruit crop.

\section{Materials and Methods}

The present investigation was carried out during the year 2017 at Fruit Research Farm, Department of Fruit Science, College of Horticulture and Forestry, Central Agricultural University, Pasighat, Arunachal Pradesh which is geographically located at $28^{\circ} 04^{\prime} 43^{\prime \prime}$ $\mathrm{N}$ latitude and $95^{\circ} 19^{\prime} 26^{\prime \prime} \mathrm{E}$ longitude with an altitude of $153 \mathrm{~m}$ above mean sea level. Seven (7) years old Assam Lemon trees planted at a spacing of $3 \mathrm{~m} \times 3 \mathrm{~m}$ were used as experimental materials and the experiment was laid out in
Randomized Block Design (RBD) consisting of 9 (nine) treatments and 5 (five) replications with one plant in each treatment. The details of the treatments are $\mathrm{T}_{1}$ (NAA @ $10 \mathrm{ppm}+$ $1 \%$ urea), $\mathrm{T}_{2}(2,4-\mathrm{D} @ 10 \mathrm{ppm}+1 \%$ urea $), \mathrm{T}_{3}$ (NAA@20 ppm + 1\% urea), T4 (2,4-D @20 ppm + 1\% urea), $\mathrm{T}_{5}$ (NAA @ 10 ppm + 2,4-D @ 10 ppm + 1\% urea), T 6 (NAA @ 20 ppm + 2,4-D@20 ppm + 1\% urea), T 7 (NAA@ 10 ppm + 2,4-D@10 ppm), T8 (NAA@ 20 ppm $+2,4-\mathrm{D} @ 20 \mathrm{ppm})$ and $\mathrm{T}_{9}$ (Control). The recommended dose of fertilizer (RDF) 100:100:100 g NPK/plant/year with $20 \mathrm{Kg}$ FYM was applied to all the plants under study before flowering (half dose during January and the remaining half during August). Two synthetic auxins viz., 2,4-dichlorophenoxy acetic acid (2,4-D) and Naphthalene acetic acid (NAA) @ 10 ppm and 20 ppm were applied as foliar spray to the plants. Since they are insoluble in water, 2,4-D and NAA were initially dissolved in a small amount of 70$80 \%$ ethanol and $1 \mathrm{~N}$ sodium hydroxide $(\mathrm{NaOH})$ respectively and then brought to the required volume with water for preparation of spray solutions. $1 \%$ diluted urea solution was applied to the plants as foliar spray.

To record the fruit drop \% tagging of fruits was done after fruit setting and prior to treatment application. 40 fruits /plant in summer season crop and 20 fruits/plant in winter season crop were tagged randomly on four directions (North, South, East and West) of the plant for the observation of fruit drop $\%$. During winter there is less fruits as compared to summer season fruits so only 20 fruits/plant tagging was done during winter season. First foliar spray of PGR $(2,4-D$ and NAA @ 10ppm and 20ppm) and urea (1\%) was applied after fruit setting and the second spray was applied at fully developed stage of fruits. Number of the tagged fruits retained on the plant was counted three weeks after application of treatment and thereafter every month till harvesting of the fruits. Observations recorded during field experiment 
were subjected to the statistical analysis of variance for RBD. The statistical analysis of the data on the mean values of individual characters was analyzed using $M$ State software. Significance and non-significance of the variance due to different treatments was determined by calculating the respective ' $\mathrm{F}$ ' values according to the method described by Gomez and Gomez (2010).

\section{Results and Discussion}

\section{Effect of PGR and urea on vegetative growth parameters}

Plant height was found to be non- significant to the application of PGR and urea (Table 1). However, maximum increase in plant height was observed in $\mathrm{T}_{6}(12.50 \mathrm{~cm})$ and minimum was observed in control $(8.75 \mathrm{~cm})$. The effect of the treatments was found to be non significant on canopy spread in North-South direction (Table 1). However, highest increase in canopy spread $(\mathrm{N}-\mathrm{S})$ was found in $\mathrm{T}_{6}(12.25$ $\mathrm{cm})$ and lowest was recorded in control $(9.50$ $\mathrm{cm})$. The treatments were also found to have a non significant effect on canopy spread in East-West direction (Table 1). However, highest increase in canopy spread (E-W) was recorded in $\mathrm{T}_{6}(11.73 \mathrm{~cm})$ and lowest was observed in control $(9.25 \mathrm{~cm})$. Similarly, Prasad et al., (2015) reported that in Kinnow Mandarin the plant growth regulators when applied in combination with urea were more effective in enhancing the vegetative growth of the plant rather than the application of PGRs alone. The role of urea in promoting plant growth may be attributed to nitrogen being a key elemental component of chlorophyll, the compound by which plants absorb sunlight energy to convert atmospheric carbon dioxide to carbohydrates through photosynthesis. Carbohydrates thus produced provide energy for plant growth and development. Increase in plant growth with foliar application of urea. Besides, Singh et al., (2017a) also reported similar effect of PGR in the vegetative growth in guava.
Effect of PGR and urea on fruit drop \% and yield attributing parameters

The effect of different treatments on the number of fruits/plant at harvesting stage was found to be highly significant (Table 2). Number of fruits/plant during summer season was comparatively more than that in the winter season apparently due to profuse flowering during summer season crop. In both the seasons, $\mathrm{T}_{6}$ was found to be the best treatment with 96.80 fruits/plant in summer season crop and 38.40 fruits/plant in winter season crop. Consequently, in the pool data, maximum number of fruits was recorded in treatment $\mathrm{T}_{6}(67.60)$ which is at par with $\mathrm{T}_{5}$ (64.40) and lowest was recorded in control plants (37.90). Due to higher flowering tendency during summer in comparison to winter season crop, fruit yield per plant was higher in summer $(12.58 \mathrm{~kg})$ than the winter crop $(4.00 \mathrm{~kg})$ which was observed in $\mathrm{T}_{6}$.

Pool data for this character inevitably recorded highest value in treatment $\mathrm{T}_{6}(8.29 \mathrm{~kg})$ which is at par with $\mathrm{T}_{5}(7.78 \mathrm{~kg})$ and lowest yield was recorded in control plants $(4.14 \mathrm{~kg})$ in which lowest fruit drop percentage was recorded in treatment $\mathrm{T}_{6}(13.91 \%)$ which is at par with $\mathrm{T}_{5}(14.24 \%), \mathrm{T}_{8}(17.31 \%)$ and $\mathrm{T}_{7}$ (19.46\%) and the highest fruit drop percentage was observed in control plants (33.15\%). Abscission of fruit is largely associated with the balance between auxin and ethylene that controls the cell separation processes (Khan et al., 2014). The dependence of abscission relative to the endogenous content of auxins has been proven by exogeneous application of 2,4-D or NAA, as the transportation of auxins by the plant lasts for a long time without ethylene appearing to affect it (Suman et al., 2017). Reduction in fruit drop percentage may be due to the action of auxin in strengthening the cells in the abscission zone which is localised at the peduncle (Stewart and Hield, 1950) (Fig. 1-4 and Table 3). 
Table.1 Effect of PGR and urea on plant height and canopy spread (N-S and E-W directions) of lemon cv. Assam Lemon

\begin{tabular}{|c|c|c|c|c|c|c|c|c|c|}
\hline \multirow[t]{2}{*}{ Treatments } & \multicolumn{3}{|c|}{ Increase in plant height $(\mathrm{cm})$} & \multicolumn{3}{|c|}{ Increase in canopy spread (North- South) $(\mathrm{cm})$} & \multicolumn{3}{|c|}{ Increase in canopy spread (East- West) (cm) } \\
\hline & Summer & Winter & Pool & Summer & Winter & Pool & Summer & Winter & Pool \\
\hline $\mathrm{T}_{1}$ & 11.00 & 10.00 & 10.50 & 11.00 & 9.50 & 10.25 & 10.00 & 10.50 & 10.25 \\
\hline $\mathrm{T}_{2}$ & 11.00 & 10.50 & 10.75 & 11.00 & 10.00 & 10.50 & 10.00 & 11.00 & 10.50 \\
\hline $\mathrm{T}_{3}$ & 11.50 & 11.00 & 11.25 & 11.00 & 11.00 & 11.00 & 11.00 & 10.20 & 10.60 \\
\hline $\mathrm{T}_{4}$ & 12.50 & 11.00 & 11.75 & 11.50 & 11.00 & 11.25 & 11.20 & 10.80 & 11.00 \\
\hline $\mathrm{T}_{5}$ & 12.00 & 11.50 & 11.75 & 12.74 & 11.00 & 11.87 & 11.20 & 11.75 & 11.47 \\
\hline $\mathrm{T}_{6}$ & 12.70 & 12.30 & 12.50 & 12.60 & 11.90 & 12.25 & 11.86 & 11.60 & 11.73 \\
\hline $\mathrm{T}_{7}$ & 11.00 & 9.00 & 10.00 & 10.00 & 9.50 & 9.75 & 9.50 & 10.00 & 9.75 \\
\hline $\mathrm{T}_{8}$ & 9.50 & 9.50 & 9.50 & 10.50 & 9.00 & 9.75 & 9.50 & 9.50 & 9.50 \\
\hline $\mathrm{T}_{9}$ & 8.50 & 9.00 & 8.75 & 10.00 & 9.00 & 9.50 & 9.00 & 9.50 & 9.25 \\
\hline SEm \pm & 1.44 & 1.37 & 1.07 & 0.90 & 1.39 & 0.79 & 1.20 & 0.90 & 0.60 \\
\hline $\mathrm{CD}(5 \%)$ & NS & NS & NS & NS & NS & NS & NS & NS & NS \\
\hline
\end{tabular}

Table.2 Effect of PGR and urea on fruit drop \% and yield attributing parameters of lemon cv. Assam lemon

\begin{tabular}{|c|c|c|c|c|c|c|c|c|c|c|c|c|}
\hline \multirow[t]{2}{*}{$\begin{array}{l}\text { Treat- } \\
\text { ments }\end{array}$} & \multicolumn{3}{|c|}{$\begin{array}{c}\text { Number of fruits/plant after } \\
\text { fruit set }\end{array}$} & \multicolumn{3}{|c|}{$\begin{array}{c}\text { Number of fruits/plant at } \\
\text { harvesting stage }\end{array}$} & \multicolumn{3}{|c|}{ Fruit drop (\%) } & \multicolumn{3}{|c|}{ Yield (Kg/Plant) } \\
\hline & Summer & Winter & Pool & Summer & Winter & Pool & Summer & Winter & Pool & Summer & Winter & Pool \\
\hline $\mathrm{T}_{1}$ & 89.60 & 33.4 & 61.50 & 63.00 & 22.20 & 42.60 & 29.50 & 24.17 & 26.83 & 7.67 & 1.72 & 4.69 \\
\hline $\mathrm{T}_{2}$ & 90.80 & 35.00 & 62.90 & 64.40 & 21.00 & 42.70 & 28.00 & 24.43 & 26.22 & 7.92 & 1.72 & 4.82 \\
\hline $\mathrm{T}_{3}$ & 90.80 & 34.60 & 62.70 & 64.60 & 23.20 & 43.90 & 27.50 & 22.40 & 24.95 & 8.17 & 2.05 & 5.10 \\
\hline $\mathrm{T}_{4}$ & 96.00 & 37.60 & 66.80 & 70.80 & 25.80 & 48.30 & 25.28 & 18.13 & 21.71 & 9.10 & 2.40 & 5.75 \\
\hline $\mathrm{T}_{5}$ & 108.80 & 42.20 & 75.50 & 92.00 & 36.80 & 64.40 & 14.50 & 13.98 & 14.24 & 11.88 & 3.67 & 7.78 \\
\hline $\mathrm{T}_{6}$ & 109.00 & 41.20 & 75.10 & 96.80 & 38.40 & 67.60 & 14.21 & 13.62 & 13.91 & 12.58 & 4.00 & 8.29 \\
\hline $\mathrm{T}_{7}$ & 97.80 & 38.80 & 68.30 & 73.20 & 35.60 & 54.40 & 22.06 & 16.86 & 19.46 & 9.44 & 3.56 & 6.49 \\
\hline $\mathrm{T}_{8}$ & 109.80 & 40.80 & 75.30 & 89.60 & 36.00 & 62.80 & 18.28 & 16.33 & 17.31 & 11.62 & 3.79 & 7.71 \\
\hline $\mathrm{T}_{9}$ & 90.00 & 34.00 & 62.00 & 57.40 & 18.40 & 37.90 & 35.01 & 31.28 & 33.15 & 6.93 & 1.36 & 4.14 \\
\hline $\mathrm{SEm} \pm$ & 10.95 & 4.81 & 5.96 & 6.89 & 5.29 & 5.05 & 4.14 & 3.89 & 2.73 & 0.91 & 0.61 & 0.65 \\
\hline $\mathrm{CD}(5 \%)$ & NS & NS & NS & 19.84 & 15.25 & 14.56 & 11.93 & 11.21 & 7.88 & 2.62 & 1.75 & 1.88 \\
\hline
\end{tabular}


Table.3 Effect of PGR and urea on harvesting period and physical parameter of lemon cv. Assam Lemon

\begin{tabular}{|c|c|c|c|c|c|c|c|c|c|c|c|c|}
\hline \multirow[t]{2}{*}{$\begin{array}{l}\text { Treat- } \\
\text { ments }\end{array}$} & \multicolumn{3}{|c|}{$\begin{array}{l}\text { Harvesting period (Number } \\
\text { of days) }\end{array}$} & \multicolumn{3}{|c|}{ Fruit length $(\mathrm{cm})$} & \multicolumn{3}{|c|}{ Fruit diameter $(\mathrm{cm})$} & \multicolumn{3}{|c|}{ Fruit fresh weight (g) } \\
\hline & Summer & Winter & Pool & Summer & Winter & Pool & Summer & Winter & Pool & Summer & Winter & Pool \\
\hline $\mathrm{T}_{1}$ & 101.00 & 98.00 & 99.50 & 8.54 & 6.96 & 7.75 & 5.04 & 4.69 & 4.86 & 121.54 & 76.47 & 99.00 \\
\hline $\mathrm{T}_{2}$ & 97.00 & 98.00 & 97.50 & 8.57 & 7.40 & 7.98 & 5.07 & 4.65 & 4.86 & 123.02 & 79.80 & 101.41 \\
\hline $\mathrm{T}_{3}$ & 97.00 & 98.00 & 97.50 & 8.58 & 7.48 & 8.03 & 5.10 & 4.78 & 4.94 & 126.40 & 84.93 & 105.66 \\
\hline $\mathrm{T}_{4}$ & 97.00 & 99.00 & 98.00 & 8.70 & 7.69 & 8.20 & 5.19 & 4.78 & 4.98 & 128.21 & 87.03 & 107.62 \\
\hline $\mathrm{T}_{5}$ & 103.00 & 100.00 & 101.50 & 9.00 & 7.98 & 8.49 & 5.34 & 5.27 & 5.30 & 130.52 & 102.59 & 116.56 \\
\hline $\mathrm{T}_{6}$ & 99.00 & 100.00 & 99.50 & 9.60 & 8.10 & 8.84 & 5.40 & 5.34 & 5.36 & 132.24 & 105.12 & 118.68 \\
\hline $\mathrm{T}_{7}$ & 99.00 & 98.00 & 98.50 & 8.75 & 7.82 & 8.28 & 5.24 & 4.84 & 5.04 & 129.03 & 95.98 & 112.52 \\
\hline $\mathrm{T}_{8}$ & 99.00 & 99.00 & 99.00 & 8.78 & 7.85 & 8.31 & 5.30 & 4.96 & 5.13 & 129.47 & 99.62 & 114.54 \\
\hline $\mathrm{T}_{9}$ & 99.00 & 98.00 & 98.50 & 8.44 & 6.64 & 7.54 & 5.01 & 4.26 & 4.63 & 118.46 & 73.74 & 96.10 \\
\hline $\mathrm{SEm} \pm$ & 2.13 & 1.43 & 1.33 & 0.23 & 0.30 & 0.20 & 0.09 & 0.21 & 0.12 & 2.17 & 6.20 & 3.52 \\
\hline $\begin{array}{c}\mathrm{CD} \\
(5 \%)\end{array}$ & NS & NS & NS & 0.66 & 0.86 & 0.57 & 0.27 & 0.62 & 0.35 & 6.24 & 17.87 & 10.14 \\
\hline
\end{tabular}




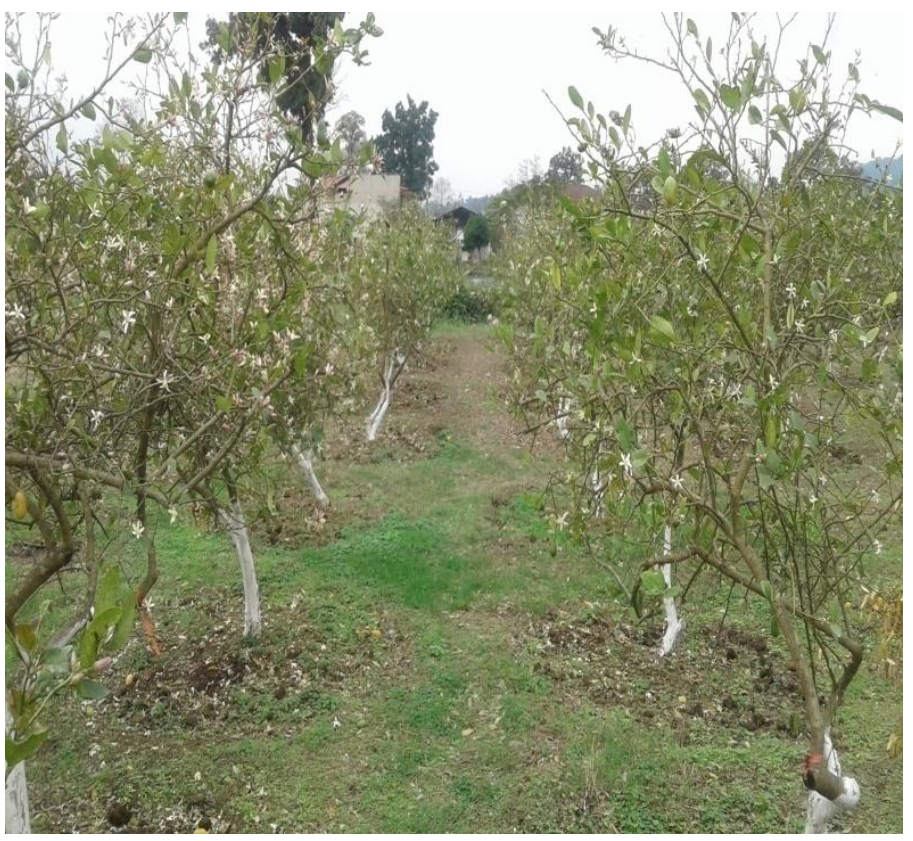

Fig.1 Flowering and fruit setting period

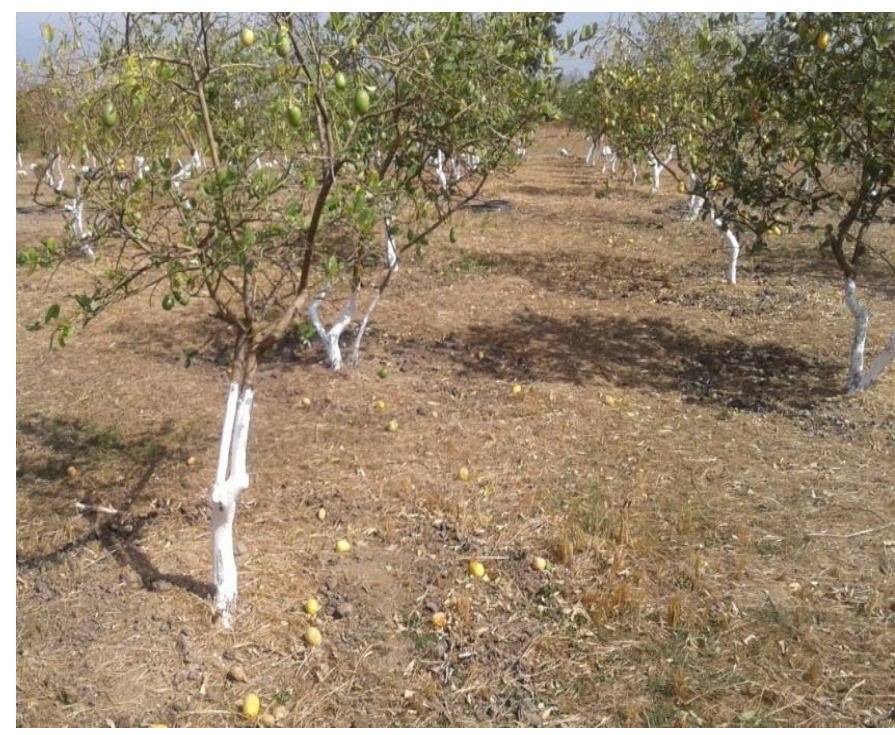

Fig.3 Pre-harvest drop

Similar findings were concurred by Almeida et al., (2004) and Nawaz et al., (2008) where the application of 2, 4-D and NAA reduced the natural fall rate when compared to control. Modise et al., (2009) also concluded that the application of 2,4-D @ 20 ppm significantly reduced fruit drop by more than $50 \%$ in sweet orange. Further, studies in Satsuma Mandarin revealed that application of 2,4-D and NAA

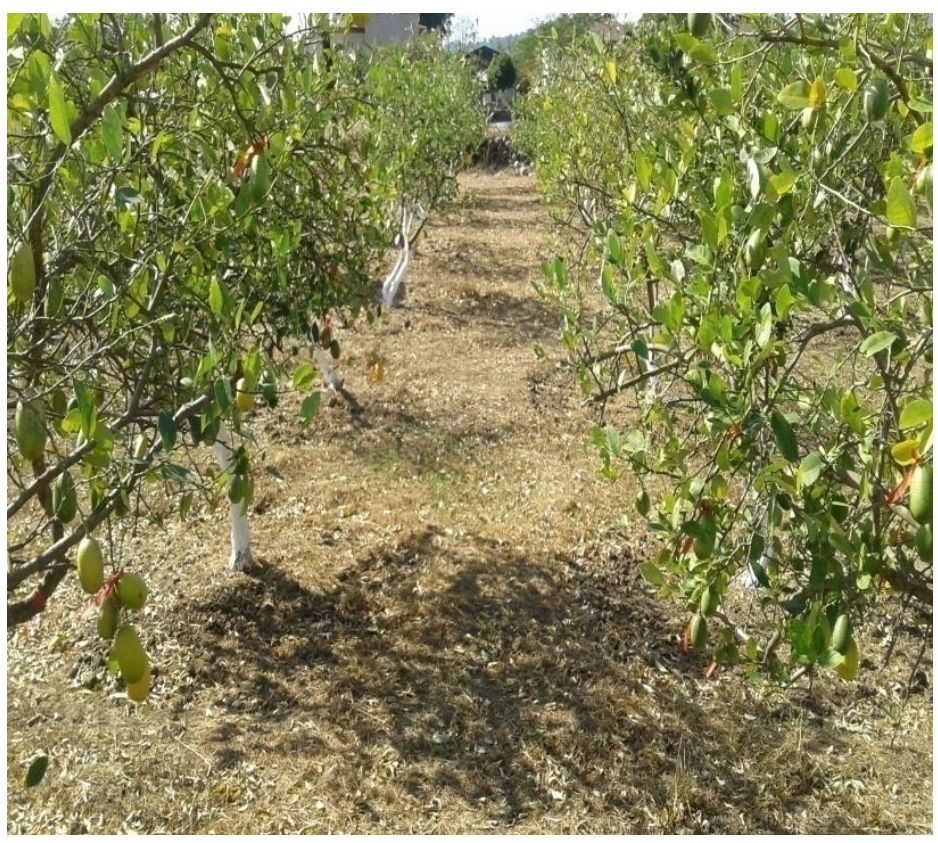

Fig.2 Tagging of the fruiting branches

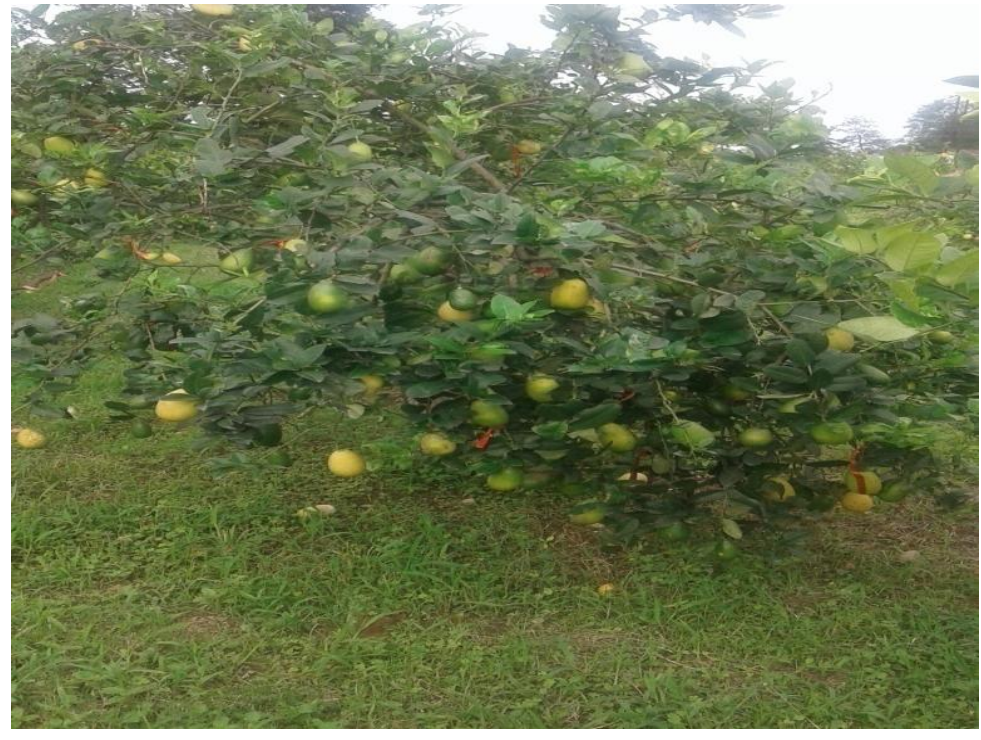

Fig.4 Heavy bearing after spraying of PGR and urea

significantly reduced pre harvest drop as compared to control (Amiri et al., 2012). In the present investigation, it was observed that NAA and 2,4-D when applied in combination with $1 \%$ urea gave superior effect in reducing fruit drop. This may be due to the enhancement in vegetative growth leading to the production of more photosynthates. This finding is in conformity with Singh et al., 
(2017b) who reported that foliar application of urea $(1 \%)+2$, 4-D (15 ppm) can be used to control fruit drop in Khasi Mandarin.

The increase in yield/plant and number of fruits/plant may be attributed to the reduction in fruit drop under the effect of plant growth regulators and urea. Bhatt et al., (2016) also recorded maximum number of fruits per plant in Pant Lemon-1 @ 10 ppm NAA foliar application. The effect of PGR and urea foliar spray has no significant influence different treatments on the parameter harvesting period. However, longest harvesting period was observed in treatment $\mathrm{T}_{5}$ (101.50 days) followed by $\mathrm{T}_{6}$ and $\mathrm{T}_{1}$ (99.50 days) and shortest harvesting period was recorded in $\mathrm{T}_{4}$ (98.00 days). The effect of different treatments on fruit length was found to be highly significant in which maximum fruit length was recorded in treatment $\mathrm{T}_{6}(8.84 \mathrm{~cm})$ which is at par with $\mathrm{T}_{5}(8.49 \mathrm{~cm}), \mathrm{T}_{8}(8.31$ $\mathrm{cm})$ and $\mathrm{T}_{7}(8.28 \mathrm{~cm})$ and minimum was observed in control plants $(7.54 \mathrm{~cm})$. Similarly the treatment has significant effect on fruit diameter also in which maximum fruit diameter was recorded in treatment $\mathrm{T}_{6}(5.36$ $\mathrm{cm})$ which is at par with $\mathrm{T}_{5}(5.30 \mathrm{~cm}), \mathrm{T}_{8}$ $(5.13 \mathrm{~cm})$ and $\mathrm{T}_{7}(5.04 \mathrm{~cm})$ and minimum fruit diameter was found in control plants $(4.63 \mathrm{~cm})$. As a result of significant effect on fruit length and breadth by PGR and urea foliar spray resulting maximum fresh weight of the fruit was observed in treatment $\mathrm{T}_{6}$ (118.68 g) which is at par with $\mathrm{T}_{5}(116.56 \mathrm{~g})$, $\mathrm{T}_{8}(114.54 \mathrm{~g})$ and $\mathrm{T}_{7}(112.52 \mathrm{~g})$ and the minimum fresh weight was found in control plants $(96.10 \mathrm{~g})$.

The improvement in overall physical characters (fruit length, breadth and fruit weight) of the fruit may be due to the contribution of auxin in fruit development which is based on a greater cell expansion. This expansion is probably due to an increase in cell vacuolisation that, in turn, increases vesicle size, locule dimensions and final fruit size (El-Otmani et al., 1993; Guardiola and Lazaro, 1987).

These findings are in concordance with the results of Verma et al., (2018) also revealed that 2\% urea spray along with PGR increased the fruit weight of Nagpur Mandarin. Therefore, the combination of recommended dose of fertilizers 100:100:100g NPK/plant/year along with $20 \mathrm{Kg}$ FYM and synthetic PGR NAA @ 20 ppm + 2,4-D @ 20 ppm $+1 \%$ urea foliar spray twice (after fruit setting and fully developed stage) were found to be efficient for increasing yield and productivity in Assam Lemon which can be recommended to reduced the fruit drops which is a major physiological disorder which hamper the yield of this important lemon cultivar in North East India.

\section{Acknowledgement}

We are obliged to the Department of Fruits, College of Horticulture and Forestry, Central Agricultural University, Pasighat, Arunachal Pradesh for the cooperation during the research.

\section{References}

Agustí, M., Juan, M., Martínez-Fuentes, A., Mesejo, C., Reig, C. and Almela, V. 2006. Application of 2,4dichlorophenoxypropionic acid 2ethylhexyl reduces mature fruit abscission in citrus Navel cultivars. $J$. Hortic. Sci. Biotechnol. 81: 532-536.

Almeida, I.M.L., Rodrigues, J.D. and Ono, E.O. 2004. Application of plant growth regulators at pre-harvest for fruit development of 'PERA' oranges. Braz. Arch. Biol. Technol. 47(4): 511520.

Amiri, N.A., Kangarshahi, A.A. and Arzani, K. 2012. Reducing of citrus losses by spraying of synthetic auxins. Int. J. 
Agric. Crop Sci. 4(22): 1720-1724.

Ashraf, M.Y., Yaqub, M., Akhtar, J., Khan, M.A., Khan, M.A. and Ebert, G. 2012. Control of excessive fruit drop and improvement in yield and juice quality of Kinnow (Citrus deliciosa x Citrus nobilis) through nutrient management. Pak. J. Bot. 44: 259-265.

Bhatt, B.B., Rawat, S.S., Naithani, D.C., Kumar, D. and Singh, K.K. 2016. Effect of foliar application of bioregulators and nutrients on growth and yield characters of lemon (Citrus limon Burm.) cv. Pant Lemon-1 under subtropical condition of Garhwal region. Plant Arch. 16(2): 821-825.

Chattopadhyay, T.K. 2007. A textbook on pomology: Subtropical fruits, Vol.-III, second ed. Kalyani Publishers, Ludhiana, pp. 2-19.

Devi, H.L., Sarkar, S.K., Dhanabati, L. and Majhi, D. 2011. Flushing - flowering behavior and regulation in acid lime A critical review and research interventions. J. Crop Weed. 7(2):8790.

El-Otmani, M., Agusti, M., Aznar, M. and Almela, V. 1993. Improving the size of 'Fortune' mandarin fruits by the auxin 2,4-DP. Sci. Hortic., 55: $283-$ 290.

Gomez, A.K. and Gomez, A.A. 2010. Statistical procedures for agricultural research, second ed. Wiley India Private Limited, New Delhi, pp. 134138.

Guardiola, J.L. and Lazaro, E. (1987). The effect of synthetic auxins on fruit growth and anatomical development in 'Satsuma' mandarin. Sci. Hortic., 31(1-2): 119-130.

Khan, A.S., Shaheen, T., Malik, A.U., Rajwana, I.A., Ahmad, S. and Ahmad, I. 2014. Exogenous applications of plant growth regulators influence the reproductive growth of Citrus sinensis
Osbeck cv. Blood Red. Pak. J. Bot. 46(1): 233-238.

Lima, W.G., Sposito, M.B., Amorim, L., Goncalves, F.P. and de Filho, P.A.M. 2011. Colletotrichum gleosporioides, a new causal agent of citrus postbloom fruit drop. Eur. J. Plant Pathol. 131: 157- 165.

Modise, D.M., Likuku A.S., Thuma, M. and Phuti, R. 2009. The influence of exogenously applied 2,4dichlorophenoxyacetic acid on fruit drop and quality of Navel oranges (Citrus sinensis L.). Afr. J. Biotechnol. 8(10): 2131-2137.

Nawaz, M.A., Ahmad, W., Ahmad, S. and Khan, M.M. 2008. Role of growth regulators on pre harvest fruit drop, yield and quality in Kinnow mandarin. Pak. J. Bot. 40(5): 1971-1981.

Prasad, H., Prasad, D. and Gupta, A.K. 2015. Effect of foliar application of 2,4-D, urea and zinc sulphate on fruit drop, yield and fruit quality of Kinnow mandarin. Int. J. Bio-Resour. Stress Manage. 6(5): 619-622.

Randhawa, G.S. and Srivastava, K.C. 1986. Citriculture in India. Hindustan Publishing Corporation, New Delhi, pp. 358-361.

Singh, R.K., Prasad, V.M., Mishra, S., Shabi, M. and Deepanshu 2017a. Studies on the effect of foliar application of nitrogen and phosphorus on growth, flowering and fruiting of Guava (Psidium guajava L.) cv. Allahabad Safeda. Pharm. Innov. J. 6(11): 771774.

Singh, S.R., Phurailatpam, A.K., Wangchu, L., Ngangbam, P. and Chanu, T.M. 2014. Traditional medicinal knowledge of underutilized minor fruits as medicine in Manipur. Int. J. Agric. Sci. 4(8): 241-247

Singh, S.R., Wangchu, L., Singh, B., Hazarika, B.N. and Pandey, A.K. 
2017b. Effect of PGRs combination on pre- harvest fruit drop of Khasi mandarin (Citrus reticulata Blanco). Indian J. Agric. Res. 51(2): 167-172.

Stewart, W.S. and Hield, H.Z. 1950. Effects of 2,4-dichlorophenoxyacetic acid and 2,4,5-Trichlorophenoxyacetic acid on fruit drop, fruit production, and leaf drop of lemon trees. Proc. Am. Soc. Hortic. Sci. 55: 163-171.

Su, H.C.F. and Horvat, R. 1982. Isolation and charcterisation of four major compounds from insecticidally active lemon peel extract. J. Agric. Food
Chem. 35(4): 509-511.

Suman, M., Sangma, P.D., Meghawal, D.R. and Sahu, O.P. 2017. Effect of plant growth regulators on fruit crops. $J$. Pharmacogn. Phytochem. 6(2): 331337.

Verma, O., Thakre, B. and Soni, U. 2018. Chemical control of pre harvest fruit drop in Nagpur mandarin (Citrus reticulata) of Chhindwara district of Madhya Pradesh, India. Int. J. Curr. Microbiol. App. Sci., 7(1): 2258-2263.

\section{How to cite this article:}

Bidyarani Devi Senjam, S.R. Singh and Hau Ngaih Lian. 2018. Effect of Different PGR and Urea on Fruit Drop and Yield of Assam Lemon [Citrus limon (L.) Burm.]. Int.J.Curr.Microbiol.App.Sci. 7(07): 2884-2892. doi: https://doi.org/10.20546/ijcmas.2018.707.338 